\title{
CLINICAL ASSESSMENT OF LANGUAGE DEVELOPMENT IN CHILDREN AT AGE 3 YEARS THAT WERE BORN PRETERM
}

\author{
Carolina Rizzotto Schirmer', Mirna Wetters Portuguez², Magda Lahorgue Nunes³
}

\begin{abstract}
Objective: To evaluate the influence of gestational age and birth weight on language development and neurodevelopmental outcome at age 3 years in children born preterm. Method: Cross sectional study including 69 children followed in our developmental outpatient clinic. Patients were consecutively included at the time of the 3 years of age appointment and stratified for birth weight (<1500 grams and between 1500-2500 grams). All patients were assessed for receptive and expressive language, Denver II and Bayley II tests and clinical neurological examination. For analysis patients were divided in two groups n o rmal language acquisition (NLA) and delay in language acquisition (DLA). Results: NLA children had higher scores on mental and psychomotor $(p=<0.01, p=0.012)$ indexes of Bayley II. Newborns with less than 1500 grams had lower scores on all Bayley scale at age 36 months $(p=0.002, p=0.007$ and $p<0.001)$. Multivariate analysis suggests an association between gestational age $(p=0.032)$, abnormal behavior $(p<0.001)$ and delay in language acquisition. Denver test at 12 and 24 months of age was a good predictor of delayed receptive and expressive language at three years of age $(p=<0.01$ and $p=<0.01)$. Conclusion: Children born prematurely with low birth weight had an increased risk of language acquisition delay, and those had also lower cognitive and behavior scores when compared to NLA.
\end{abstract}

KEY WORDS: prematurity, low birth weight, language acquisition, developmental delay, Bayley infant scale, Denver test.

\begin{abstract}
Avaliação da evolução dos aspectos linguísticos em crianças que nasceram prematuras aos 3 anos de idade

RESUMO - Objetivo: Avaliar influência da idade gestacional (IG) e peso ao nascimento na aquisição da linguagem e neurodesenvolvimento em crianças de 3 anos que nasceram prematuras. Método: Estudo transversal incluindo 69 crianças acompanhadas no Ambulatório de Seguimento Neonatal. Pacientes incluídos tinham 3 anos e foram estratificados por peso ao nascimento (>1500 gramas e entre 1500-2500 gramas). Todos foram avaliados com relação ao neurodesenvolvimento incluindo avaliação neurológica clínica, Denver II, Bayley II e avaliação da linguagem. Para a analise dividimos em dois grupos com e sem alteração na aquisição de linguagem. Resultados: Crianças com DAL apresentam melhores índices nos escores de desenvolvimento no Bayley II $(p=<0.01$ e $p=0.012)$. Crianças que nasceram com peso $>1500$ gramas tiveram escores menores no Bayley II na idade de $36 \mathrm{~m}(p=0.002, p=0.007$ e $p<0.001)$. Análise multivariada sugere uma associação da IG $(p=0,032)$ e alteração comportamental $(p=0,001)$ com atraso na aquisição da linguagem. Denver II alterado tanto aos $12 \mathrm{~m}$ quanto aos $24 \mathrm{~m}$, correlaciona-se com significância estatística a atraso na aquisição de linguagem receptiva e expressiva aos 3 anos de idade $(p=<0.01$ e $p=<0.01)$. Conclusão: Crianças nascidas prematuras e com baixo peso ao nascimento, apresentam maior risco de ter um atraso no desenvolvimento da linguagem. Sendo que as crianças que tem atraso no desenvolvimento de linguagem apresentaram um desempenho cognitivo e psicomotor inferior ao das com desenvolvimento normal.
\end{abstract}

PALAVRAS-CHAVE: p rematuridade, baixo peso ao nascimento, aquisição de linguagem, atraso no desenvolvimento, escala infantil Bayley, teste de Denver.

Even though technical and scientific advances have expressively contributed to the reduction of preterm newborn mortalility, prematurity and low birth weight still rise as the causes of mortality and neonatal morbidity, promoting a strong clinical and epidemiological impact. The risks of deviations in the development of these infants are consistent not only because they are more sensitive to diseases but also

Division of Neurology - Hospital São Lucas and School of Medicine Pontifícia Universidade Católica do Rio Grande do Sul (PUCRS) Po rto Alegre RS - Brazil: 'Language Therapist - Fellow Developmental Outpatient Clinic HSL - PUCRS; ${ }^{2}$ MD, Associate Professor of Neurology, PUCRS School of Medicine; ${ }^{3} \mathrm{MD}$, PhD Associate Professor of Neurology and Pediatrics, PUCRS School of Medicine.

Received 22 March 2006, received in final form 4 July 2006. Accepted 10 August 2006.

Dra. Magda Lahorgue Nunes - Division of Neurology - Hospital São Lucas - PUCRS - Avenida Ipiranga 6690 / 220 - CEP $90610-000$ Porto Alegre RS - Brasil. E -mail: nunes@pucrs.br 
because they are exposed to iatrogenic factors such as long time isolation in the incubator, side effects of medications, besides mechanical ventilation and $s t$ ress due to long handling ${ }^{1-4}$. Studies show that the majority of newborns survivors of perinatal complications develop, at a later stage, multiple disorders in the first infancy or school age, including learning and language delay. Pre te rm low birth weight children may have up to four times more chances of presenting motor coordination and language acquisition delay in the third year of life than those born at a normal gestational age and weight ${ }^{5}$. Within language alterations the most significant is poverty in linguistic skills such as naming, language reception and hearing processing either in preschool age or school age ${ }^{6-8}$.

It is well known that language disorders are related to learning disorders and around $50 \%$ of children diagnosed as having language disorders at age 2 years will continue to have this problem at ages 3-4 years ${ }^{9}$. As language is considered one of the most imporant developmental milestone and as outcome studies on preterm low birth weight newborns generally focus on mortality/morbidity and global neurological outcome, we specifically designed this study to access language acquisition ${ }^{10-12}$.

The aim of this study was to evaluate the influence of gestational age and birth weight on language development and at global outcome at age 3 years in children born preterm.

\section{METHOD}

A cross sectional study was developed in a cohort of newborms admitted at the Neonatal Intensive Care Unit of Hospital São Lucas, the University Hospital of PUCRS Medical School, and followed at the Neonatal Follow up Outpatient Clinic of the same institution. The variables studied were prematurity and low birth weight and the clinical outcomes were the alteration or not of language acquisition besides mental and psychomotor development.

Patients - In this study, 69 children both $\mathrm{m}$ ale and female have been included in a consecutive way when their 3-year old appointment was scheduled at the Neonatal Follow up Outpatient Clinic. These children were born prematurely between January 1999 and April 2001 (gestational age $<37$ weeks) and with low birth weight ( $<2500$ grams), all of them belonged to lower socioeconomic classes and were admitted by the Brazilian Public Health System (SUS).

Children followed in programs of early stimulation, that were hearing impaired or had malformations of the central nervous system, as well as those who interrupted their follow up in the two first years of life or those whose the current address was unavailable, have been excluded.

The statistical Mann-Whitney test was initially applied to verify if the sample included in this study differed from the total group of children born prematurely and with low birth weight, from 1999 to 2001, in the same unit. The result obtained was that the studied group was similar in relation to gestational age but with lower birth weight.

Procedures-Perinatal clinical data have been revised in the medical records. Children were divided in two groups according to birth weight (very low birth weight $<1500$ grams and low birth weight between 1500-2500 grams).

For the evaluation of the neuropsychomotor development, the scales of Bayley II Infant Development (BSDI-II) ${ }^{13}$ and the Denver II test ${ }^{14,15}$ we re used . The cognitive and behavioral development evaluation was performed using Bayley $\mathrm{II}^{13}$. These tests are applied routinely in our Neonatal Follow Up Outpatient Clinic.

The information on the mental and neuropsychomotor development in the corrected ages of 12 months and 24 months were obtained retrospectively in the clinic medical records and were performed by the Neuropsychology and Children Neurology teams.

The evaluation at 3 years of age was done in a prospective way, by the same teams, supervised by the researchers (MWP e MLN) and complemented by the language evaluation.

The evaluation of language development was done by the observation technique of language behavior based in the Nicolosi ${ }^{16}$ Sequence of Language Development which $p$ rovides qualitative data that is, if language is adequate or altered. This evaluation was done by the researcher (CRS) that analyzed the infant's linguistic behavior having as parameters points in receptive and expressive language. The researcher was blind to the study variables.

The exam of the hearing function, which is part of the clinic routine, was done by the Speech Therapy Service, during the first year of life through the otoacustic emission test.

This project was approved by the Ethics Committee of PUCRS.

An analytic study of the frequency for the categorical data and for the comparisons among the groups with absence and presence of language alteration was done. Categorical variables were compared using the chi-square test and continuous variables were compared using the Student $T$ test. Wald test was used for the multivariate analysis.

\section{RESULTS}

During the period established for data collection 69 children were included. In the stratification according to birth weight, 39 had low birth weight $(<2500 \mathrm{~g}$ and $\leq 1500 \mathrm{~g})$ and 30 very low birth weight $(<1500 \mathrm{~g})$. Regarding language evaluation, 34 presented normal development and 35 presented altered language development.

In the group studied, 23 children had neonatal neu rological disorders such as perinatal asphyxia (9), intraventricular hemorrhage grade I (6), congenital infection (4), seizures (3) and bacterial meningitis (1). 
Table 1. Clinical characteristics between the groups with and without language alteration at 36 months of age.

\begin{tabular}{|c|c|c|c|}
\hline Characteristics & NLA $n=34$ & DLA $n=35$ & $\mathrm{p}$ \\
\hline Gestational age (weeks) & $33.18 \pm 2.58$ & $32.03 \pm 2.80$ & 0.081 \\
\hline Birthweight (grams) & $1622.79 \pm 472.49$ & $1483 \pm 475.09$ & 0.228 \\
\hline \multicolumn{4}{|l|}{ Sex } \\
\hline Male & $15(44.1)$ & $7(48.6)$ & 0.811 \\
\hline Female & $19(55.9)$ & $18(51.4)$ & - \\
\hline Neonatal neurological disorder & $12(35.3)$ & $11(31.4)$ & 0.802 \\
\hline Without neonatal neurological disorder & $22(64.7)$ & $24(68.6)$ & - \\
\hline \multicolumn{4}{|l|}{ Bayley score (36 months) } \\
\hline Mental score & $103.15 \pm 14.68$ & $88.11 \pm 110.86$ & $<0,01$ \\
\hline Psychomotor score & $105.29 \pm 13.01$ & $96.03 \pm 16.55$ & 0.012 \\
\hline $\begin{array}{l}\text { Alteration behaviour scale - } \\
\text { Bayley test ( } 36 \text { months) }\end{array}$ & $7(20.6)$ & $23(65.7)$ & $<0,01$ \\
\hline Abnormal Denver test II (36 months) & $2(5.9)$ & $11(31.4)$ & 0.012 \\
\hline Normal Denver test II (36 months) & $32(94.1)$ & $24(68.6)$ & - \\
\hline
\end{tabular}

Table 2. Clinical characteristics between the groups without and with abnormal language acquisition in relation to birthweight at 36 months of age.

\begin{tabular}{|c|c|c|c|}
\hline Variables & NLA & DLA & $\mathrm{p}$ \\
\hline \multicolumn{4}{|l|}{ Birthweigth $<1500$ grams } \\
\hline \multicolumn{4}{|l|}{$n=30$} \\
\hline \multicolumn{4}{|l|}{ Bayley score (36 months) } \\
\hline Mental score & $104.43 \pm 18.48$ & $85.25 \pm 11.13$ & 0.002 \\
\hline Psychomotor score & $109 \pm 13.79$ & $92.81 \pm 16.22$ & 0.007 \\
\hline Alteration behaviour scale - & $13(81.2)$ & $0(0)$ & $<0.01$ \\
\hline \multicolumn{4}{|l|}{ Bayley Test (36 months) } \\
\hline Abnormal Denver test II (36 months) & $2(14.3)$ & $5(31.3)$ & 0.399 \\
\hline Normal Denver test II (36 months) & $12(85.7)$ & $11(68.8)$ & - \\
\hline \multicolumn{4}{|l|}{ Brithweigth $1500-2500$ grams } \\
\hline \multicolumn{4}{|l|}{$n=36$} \\
\hline \multicolumn{4}{|l|}{ Bayley score (36 months) } \\
\hline Mental score & $102.25 \pm 11.76$ & $90.53 \pm 10.31$ & 0.002 \\
\hline Psychomotor score & $102.70 \pm 12.12$ & $98.74 \pm 16.78$ & 0.401 \\
\hline Alteration behavior scale - & $7(35)$ & $10(52.6)$ & 0.341 \\
\hline \multicolumn{4}{|l|}{ Bayley test (36 months) } \\
\hline $\begin{array}{l}\text { Without alteration behavior scale - } \\
\text { Bayley test ( } 36 \text { months) }\end{array}$ & $13(65)$ & $9(47.4)$ & - \\
\hline Abnormal Denver test II (36 months) & $0(0)$ & $6(31.6)$ & 0.008 \\
\hline Normal Denver test II (36 months) & $20(100)$ & $13(68.4)$ & - \\
\hline
\end{tabular}


Table 3. Denver test at 12 and 24 months and evaluation of language at 36 months.

\begin{tabular}{|c|c|c|c|c|c|c|c|}
\hline \multirow[b]{3}{*}{ Denver } & \multirow[b]{3}{*}{$\mathrm{n}$} & \multicolumn{6}{|c|}{ Language acquisition delay } \\
\hline & & \multicolumn{3}{|c|}{ Expressive language } & \multicolumn{3}{|c|}{ Receptive language } \\
\hline & & $f$ & $(\%)$ & $p$ & f & $(\%)$ & $\mathrm{p}$ \\
\hline \multicolumn{8}{|l|}{12 meses } \\
\hline Abnormal & 20 & 15 & $(75)$ & 0.05 & 9 & $(45)$ & $<0.01$ \\
\hline Normal & 35 & 16 & $(46)$ & - & 0 & $(0)$ & - \\
\hline \multicolumn{8}{|l|}{24 meses } \\
\hline Abnormal & & 14 & $(82)$ & 0.01 & 10 & (59) & $<0.01$ \\
\hline Normal & & 16 & $(41)$ & - & 0 & $(0)$ & - \\
\hline
\end{tabular}

Table 4. Language alteration in relation to birth weight and results of Denver test.

\begin{tabular}{|c|c|c|c|c|c|c|c|}
\hline \multirow[b]{3}{*}{ Denver } & \multirow[b]{3}{*}{$\mathrm{n}$} & \multicolumn{6}{|c|}{ Language acquisition delay } \\
\hline & & \multicolumn{3}{|c|}{ Expressive language } & \multicolumn{3}{|c|}{ Receptive language } \\
\hline & & $f$ & $(\%)$ & $\mathrm{p}$ & $f$ & $(\%)$ & $\mathrm{p}$ \\
\hline \multicolumn{8}{|c|}{ Birth weight $<1500 \mathrm{~g}$} \\
\hline \multicolumn{8}{|l|}{12 months } \\
\hline Abnormal & 10 & 7 & (78) & 0.04 & 4 & (44) & 0.007 \\
\hline Normal & 18 & 6 & (33) & - & 0 & $(0)$ & - \\
\hline \multicolumn{8}{|l|}{24 months } \\
\hline Abnormal & & 8 & $(80)$ & 0.04 & 5 & $(50)$ & 0.003 \\
\hline Normal & & 6 & (33) & - & 0 & $(0)$ & - \\
\hline \multicolumn{8}{|c|}{ Birth weight $\leq 1500 \mathrm{~g}$} \\
\hline \multicolumn{8}{|l|}{12 months } \\
\hline Abnormal & 7 & 8 & $(73)$ & 0.68 & 4 & (44) & 0.005 \\
\hline Normal & 21 & 10 & $(59)$ & - & 0 & $(0)$ & - \\
\hline \multicolumn{8}{|l|}{24 months } \\
\hline Abnormal & & 6 & $(86)$ & 0.18 & 5 & $(72)$ & $<0.01$ \\
\hline Normal & & 10 & (48) & - & 0 & (0) & - \\
\hline
\end{tabular}

The clinical characteristics and the evaluation of the neuropsychomotor development at 3 years of age in children with and without language alterations are described in Table 1.

The group without language alterations have shown better indexes in the mental and psychomotor development $(p=<0.01, p=0.012)$. Alteration in the BSDI-II behavior scale was found in $66 \%$ of patients with language alteration $(p<0.001)$. The Denver II test was abnormal in $31.4 \%$ of patients with language alteration and in $6 \%$ of those with normal language $(p=0.012)$.
Results referring the stratification by weight are described in Table 2 .

The children with birth weight lower than 1500 grams and language delay showed the worst perfo rmance in all BSDI-II when compared to those without language alteration. Children with birth weight between 1500-2500 grams and language delay showed the worst BSD-I mental score and in the Denver test $(p=0.002, p=0.008)$.

Evaluation of receptive and expressive language acquisition compared to Denver test results are described in Table 3. Altered Denver test either at 12 
Table 5. Multivariate analysis: association between gestational age, Denver test (12 and 24 months) and abnormal behavior and language alteration at 36 months of age.

\begin{tabular}{|c|c|c|c|c|c|c|}
\hline Variable & OR $(\text { IC } 95 \%)^{1}$ & p-value ${ }^{2}$ & OR (IC 95\%) ${ }^{1}$ & $\mathrm{p}$-value ${ }^{2}$ & OR (IC 95\%) ${ }^{1}$ & $p$-value ${ }^{2}$ \\
\hline \multicolumn{7}{|c|}{ Gestacional age } \\
\hline$\leq 32.5 \mathrm{wk}$ & 1 & & 1 & & 1 & \\
\hline$>32.5 \mathrm{wk}$ & $3.91(0.77-19.81)$ & 0.100 & $2.84(0.70-11.59)$ & 0.144 & $3.47(1.11-10.85)$ & $0.032^{*}$ \\
\hline \multicolumn{7}{|l|}{ Denver 12} \\
\hline Normal & 1 & & 1 & & - & - \\
\hline Abnormal & $1.85(0.25-13.39)$ & 0.543 & $3.64(0.83-16.00)$ & 0.088 & - & - \\
\hline \multicolumn{7}{|l|}{ Denver 24} \\
\hline Normal & 1 & & - & - & - & - \\
\hline Abnormal & $3.85(0.58-25.68)$ & 0.164 & - & - & - & - \\
\hline \multicolumn{7}{|c|}{ Bayley-behavioral scale } \\
\hline Normal & 1 & & 1 & & 1 & \\
\hline Abnormal & $14.04(2.78-70.97)$ & $0,001 *$ & $9.73(2.34-40.55)$ & $0.002^{*}$ & $8.47(2.66-27.00)$ & $0.000^{*}$ \\
\hline
\end{tabular}

Statistical significance, ${ }^{1}$ Odds ratio adjusted, ${ }^{2}$ Wald test.

months or at 24 months, correlates with statistic significance to the delay in the receptive and expressive language acquisition at 3 year-old children $(p=<0.01$ and $\mathrm{p}=<0.01$ ).

Language acquisition when compared in all its levels and the Denver II test among groups stratified by birth weight, we observed that the Denver altered at 12 and 24 months in children with birth weight between 2550-1500 grams is correlated with the delay in language acquisition in expressive and receptive levels. In those children with birth weight lower than 1500 grams there was a relation between alteration in the Denver and the receptive language (Table 4).

Multivariate analysis was refered in order to identify the associations among the variables gestational age, birth weight, Denver test result at 12 and 24 months, Bayley test results, Bayley test results at 36 months with the closing of language at 36 months. Only the variables with a significant association are in the multivariate analysis, that is gestational age $(p=0.04)$, Bayley test scores $(p=<0.01)$ and Bayley test behavioral score $(p=<0.01)$.

In the multivariate analysis of the association among the variables GA, Denver test at 12 months (Denver 12), Denver test at 24 months (Denver 24) and alteration in the BSDI-II behavioral score it was observed that the gestational age lower than 32 weeks increases 3 times the risk of delay in language acquisition. Alteration in behavior at 36 months has a 8 times higher risk to show language alteration (Table 5).

\section{DISCUSSION}

P rematurity and low weight, per se, are elements that constitute risk factors for development delay and are associated to either global disorders such as brain paralysis or mental retardation or specific disorders such as hearing and /or visual disorders and language alterations ${ }^{3,17}$. The impact of prematurity and low birth weight in the neuropsychomotor development (NPMD) was studied by several authors ${ }^{3,17-22}$.

Possibly, the most important aspect of our study, was the language evaluation and the valorization of both expressive and receptive level, once most studies of low birth weight premature born children related to children development are based on the mental and psychomotor development ${ }^{1-3,5,23}$.

In this investigation, the results found suggested that the pre maturewith language alteration have a tendency to show low birth weight and a smaller gestational age. In this group it was also found lower score indexes for the mental and psychomotor development. Vohr and collaborators ${ }^{1}$ in a multicentric study with the objective of detecting risk factors for the altered neurological development in premature children with extreme low weight, between 18 to 22 months of corrected age, verified that $37 \%$ showed intelligence bellow expected and $29 \%$ showed delayed in the psychomotor development. Ohgi and collaborators ${ }^{3}$ in a study with low birth premature newborns, observed that, at 5, $19,6 \%$ of children were classified as moderate handicap and $9,6 \%$ as severehandicap. Stoelhorst and collaborators ${ }^{4}$, in a 
study with extreme premature newborns, found, at 18 and 24 months of corrected age, prevalence of $40 \%$ psychomotor and mental development delay.

Another aspect raised in our investigation, similar to the one described in the literature, is the high prevalence of alteration in the expressive language acquisition process in children born premature and with low birth weight. Grunau and collaborators ${ }^{19}$ compared the language development, at 3 years old, of pre $m$ a t u rechildren born with birth weight lower than $1000 \mathrm{~g}$ with term control children paired by social class based on chronological age and corrected age. The pre-term group used less complex expressive language and showed low receptive comprehension, listening memory and verbal reasoning.

Landry and collaborators ${ }^{22}$ followed the development of low weight premature children up to 8 years of age and verified that the social economic level may influence language development. Children in our study come from a low social economic class and are seen by the Public Health System.

We observed in our study a correlation between gestational age and language development alteration, that is, the more the premature the bigger the chance of showing alteration in language development. These findings agree with Landry and collaborators $^{22}$.

It seems that the sum of factors that negatively affect the development of low birth weight premature infants involves two aspects, the exposure to unfavorable environmental factors such as, for example, the mother's low social and economic leve ${ }^{24,25}$ (that implies in little linguistic stimulation) and the physiological delay in neurobiological maturation, those aspects leads to the conclusion that not even the very active brain plasticity at this period ${ }^{26}$ can compensate in time the neurodevelopment to the point of making the acquisition of language expre ssion chronologically adequate ${ }^{27}$.

To conclude, in our sample, low birth weight premature infants showed higher risk of having language delay. Those children that have a delay in language development showed a lower cognitive and psychomotor development compared to those with normal development. Abnormalities previously detected by Denver II test were correlated with statistical significance with delay in the receptive and ex$p$ ressive language acquisition, showing that this test is a good resource to detection and early intervention in cases of prematurity and low birth weight.

\section{REFERENCES}

1. Vohr BR, Wright LL, Dusick AM, et al. Neurodevelopmental and functional outcomes of extremely low birth weight infants in the national Institute of Child Health and Human Development Neonatal Research Network, 1993-1994. Pediatrics 2000;105:1216-1226.

2. Ayoubi JM, Audibert F, Boithias C, et al. Perinatal factors affecting survival and survival without disability of extreme prematureinfants at two years of age. Eur J Obstet Gynecol Reprod Biol 2002;105:124-131.

3. Ohgi S, Arisawa K, Takahashi T, et.al. Neonatal behavioral assessment scale as a predictor of later developmental disabilities of low birthweight and/or premature infants. Brain Dev 2003;25:313-331.

4. Stoelhorst GMSJ, Rijken M, Martens SE, et al. Developmental outcome at 18 and 24 months of age in very preterm children: a cohort study from 1996 to 1997. Early Hum Dev 2003;72:83-95.

5. Ruiz-Extremera A, Robles-Vizcaino C, Salvatierra-Cuenca MT, et. al. Neu rodevelopment of neonates in neonatal intensive care units and g rowth of surviving infants at age 2 years. Early Hum Dev 2001;65:119132.

6. Jansson-Verkasalo E, Valkama M, Vainionpaa L, Paakko E, Ilkko E, Lehtihalmes M. Language development in very low birth weight preterm children: a follow up study. Folia Phoniatr Logop 2004;56:108-119.

7. Oliveira LN, Lima MC, Gonçalves VM. Follow-up of low birth weight infants: language acquisition. Arq Neuropsiquiatr 2003;61:802-807.

8. Marlow N, Wolke D, Bracewell MA, Samara M for the EPICure Study Group. Neurologic and developmental disability at six years of age after extremely preterm birth. N Engl J Med 2005;6:352:1:9-19.

9. Rescorla L. The language development survey: a screening tool for delayed in toddlers. J Speech Hear Disord 1989;54:587-599.

10. Bax M, Hart H, Jenkins S. Assessment of speech and language development in the young child. Pediatrics 1980;66:350-354.

11. Aran D, Ekelman B, Nation J. Preschoolers with language disorders: 10 years later. J Speech Hear Res 1984;27:232-244.

12. Tallal P. Developmental language disorders. In: Kavanagh, JF, Truss TJ. Learning disabilities proceedings of national conference. Parkton, York Press, 1988:181-272.

13. Bayley N. Bayley scales of infant development. San Antonio, $2^{\text {nd }}$ ed. The Psychological Corporation. Hardcourt Brace \& Company, 1993.

14. Frankenberg WK, Dodds J, Archer P, et al. Denver II screening manual. Denver: Denver Developmental Materials, Inc. 1990.

15. FrankenbergWK, Dodds J, Archer P, Shapiro H, Bresnick B.The Denver II: a major revision and restand ardization of Denver developmental screening test. Pediatrics 1992;89-91.

16. Nicolosi L, Harryman E, Kresheck J. Terminology of communication disorders: speech-language-hearing, $4^{\text {rd }}$ ed. Baltimore: Willian \& Willkins, 1996:337-340.

17. Lumley J. Defining the problem: the epidemiology of preterm birth. BJOG 2003;110:3-7.

18. Butler N, Peckham C, Sheridan M. Speech defects in children aged 7 years: a national study. Br Med J 1973;1:253-257.

19. Rocissano L, Yatchmink Y. Language skill and interactive patterns in prematurelly born toddlers. Child Dev 1983;54:1229-1241.

20. La rgo RH, Molinari L, Cemenale PL. Language development of term and preterm children during the first five years of life. Dev Med Child Neurol 1986;28:333-350.

21. Grunau RVE, Kearner SM, Whitfield MF. Language development at 3 years old in preterm children of birth weight below 1000g. Br J Disord Commun 1990;25:173-182.

22. Siegel LS, Cooper DC, Fitzhardinge PM, Ash AJ. The use of mental development index of the Bayley scale to diagnose language delay in 2-year-old high-risk infants. Dev Behav 1995;18:483-486.

23. Lewis BA, Singer LT, Fulton S, et al. Speech and language outcomes of children with bronchopulmonary dysplasia. J Commun Disord 2002; 35:393-406.

24. Landry SH, Smith KE, Swank PR. Environmental effects on language development in normal and high-risk child population. Semin Pediatr Neurol 2002;9:192-200.

25. Thal DJ, Reilly J, Seibert L, Jeffries R, Fenson J. Language development in children at risk for language impairment: cross-population comparisons. Brain Lang 2004;88:167-179.

26. Ramey CT, Ramey SL. Prevention of intellectual disabilities: early interventions to improve cognitive development. Prev Med 1998;27:224232.

27. Johnston MV. Clinical disorders of brain plasticity. Brain Dev 2004; 26:73-80. 